\title{
Stepwise drying of Lake Turkana at the end of the African Humid Period: a forced regression modulated by solar activity variations?
}

\author{
Alexis Nutz and Mathieu Schuster \\ Institut de Physique du Globe de Strasbourg (IPGS), UMR 7516, Centre National de la Recherche Scientifique, Université de \\ Strasbourg, École et Observatoire des Sciences de la Terre, 1 Rue Blessig, 67084 Strasbourg, France \\ Correspondence to: Alexis Nutz (nutz@geo.au.dk)
}

Received: 29 June 2016 - Published in Solid Earth Discuss.: 20 July 2016

Revised: 1 November 2016 - Accepted: 13 November 2016 - Published: 1 December 2016

\begin{abstract}
Although the timing of the termination of the African Humid Period (AHP) is now relatively well established, the modes and controlling factors of this drying are still debated. Here, through a geomorphological approach, we characterize the regression of Lake Turkana at the end of the AHP. We show that lake level fall during this period was not continuous but rather stepwise and consisted of five episodes of rapid lake level fall separated by episodes marked by slower rates of lake level fall. Whereas the overall regressive trend reflects a decrease in regional precipitations linked to the gradual reduction in Northern Hemisphere summer insolation, itself controlled by orbital precession, we focus discussion on the origin of the five periods of accelerated lake level fall. We propose that these periods are due to temporary reductions in rainfall across the Lake Turkana area associated with repeated westward displacement of the Congo Air Boundary $(\mathrm{CAB})$ during solar activity minima.
\end{abstract}

\section{Introduction}

The African Humid Period (AHP), ca. 14.8 to $5.5 \mathrm{kacal} \mathrm{BP}$ (kilo-annum before present), is a major climate period that was paced by orbital parameters (i.e. precession; deMenocal et al., 2000; deMenocal and Tierney, 2012; Bard, 2013; Shanahan et al., 2015) and that had a marked impact the environment, ecosystems, and human occupation of Africa (Bard, 2013). An increase in rainfall during this climate period led to the rise and highstand of numerous African lakes (Street and Grove, 1976; Tierney et al., 2011). The end of the AHP was characterized by the establishment of more arid conditions, leading to dramatic lake level falls (Street-Perrott and Roberts, 1983; Kutzbach and Street-Perrott, 1985). This aridification forced Neolithic populations to adapt to more limited resources (Kuper and Kröpelin, 2006) and represents one of the most recent examples of major climate change. The mid-Holocene termination of the AHP is thought to have been either abrupt (deMenocal et al., 2000), gradual (Kröpelin et al., 2008), or time-transgressive (Shanahan et al., 2015), depending on location. This highlights the variable responses of proxies to dominant forcings and the complex interactions among the multiple components of the local environment (e.g. deMenocal et al., 2000; Renssen et al., 2006; Liu et al., 2007; Tierney and deMenocal, 2013; Shanahan et al., 2015). However, drying trends remain poorly constrained and, in consequence, the precise modes of aridification are uncertain. A lack of continuous sedimentary archives has led to the standard idea of a relative constant rate of lake level fall during the regression of African lakes (e.g. Garcin et al., 2012; Forman et al., 2014; Morrissey and Scholz, 2014; Junginger et al., 2014; Bloszies et al., 2015). In this study, we investigate the drying trend of Lake Turkana at the end of the AHP and, for the first time, present evidence that this final regression was not continuous through time, revealing a more complex process than the traditional idea of lake regression. Understanding the mode of African lake regressions is particularly relevant in the context of projecting future global climate change impacts on the African continent (e.g. Patricola and Hook, 2011), especially in terms of evolution of water resources of large lakes.

Lake Turkana is one of the great lakes of the East African Rift system. It is considered as a wind-driven body of water (Nutz et al., 2016) that developed abundant wave-dominated coastal features along its shoreline. These coastal features 


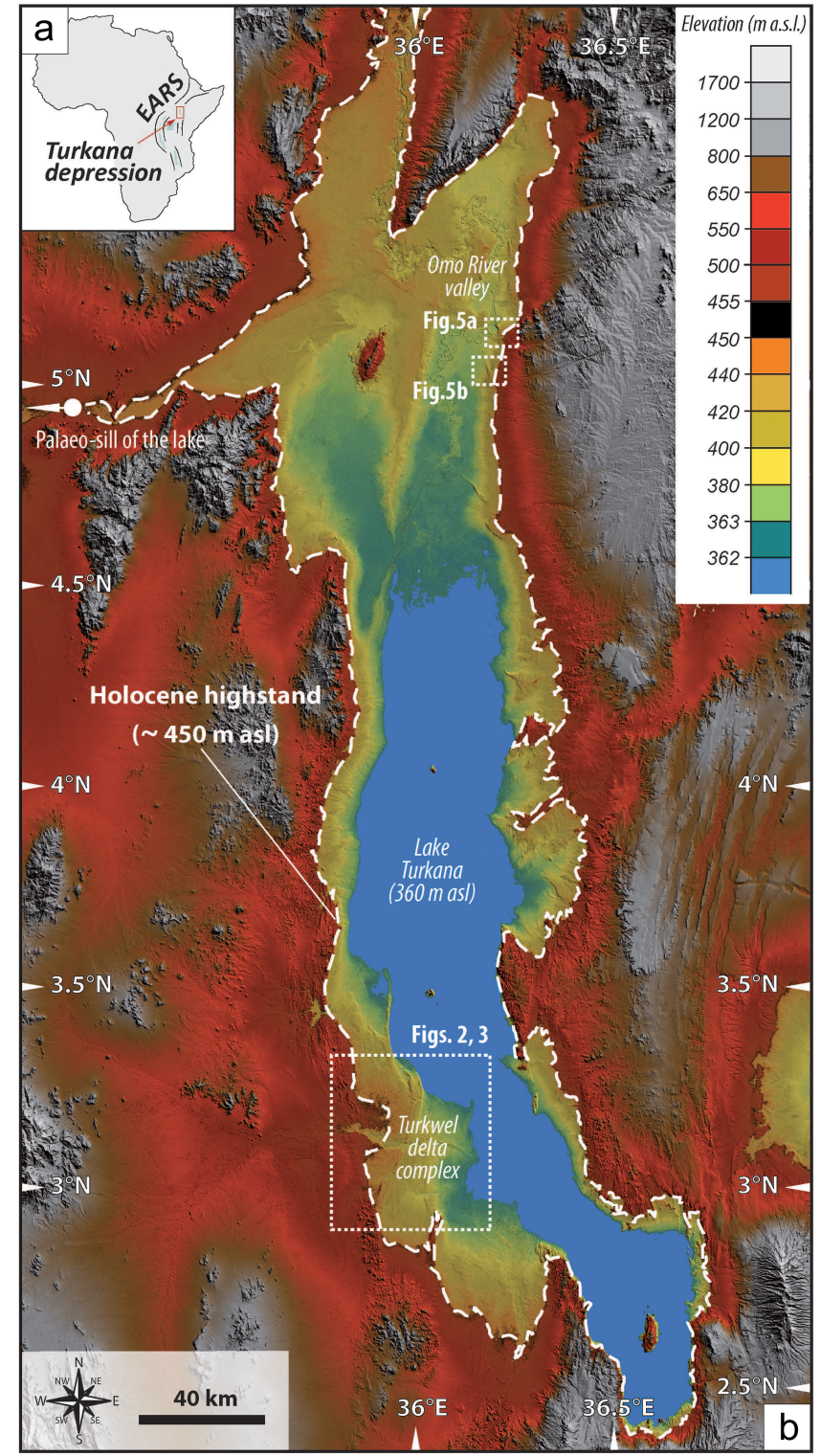

Figure 1. Location maps. (a) Lake Turkana basin in the East African Rift system (EARS). (b) Digital elevation model (DEM) SRTM1 showing Lake Turkana and the two investigated areas (Turkwel delta complex and the east side of the Omo River valley). Dashed white line represents the maximum Holocene lake level. All described geomorphological features are located between the palaeolake limit and the modern lake shoreline.

represent a valuable palaeohydrological archive that permits a greater understanding of Lake Turkana evolution during the AHP (Butzer, 1980; Owen et al., 1982; Garcin et al., 2012; Forman et al., 2014; Bloszies et al., 2015). However, the detailed and continuous evolution of lake level over the course of the last forced regression (i.e. basinward migration of the shoreline associated with a base level fall), marking the end of the AHP, has not been clearly documented. Here, the delta complex of the Turkwel River (Fig. 1), which de- veloped during the last forced regression of Lake Turkana, is examined using trajectory analysis (Helland-Hansen and Hampson, 2009). We highlight variations in the rate of lake level fall during this ultimate regression. We then interpret these variations as markers that reflect changes in precipitation during the crucial period corresponding to the terminal phase of the AHP. Subsequently, we discuss potential forcings responsible for the regressive pattern of Lake Turkana with a primary focus on the role of the Sun and short-term variations in insolation.

\section{Methods}

The dataset is comprised of satellite imagery and a digital elevation model (DEM). A recently obtained SRTM1 dataset (Shuttle Radar Topography Mission; Rabus et al., 2003) is available for the entire Lake Turkana area. This DEM is produced by radar interferometry with 1 arcsec (approximately $30 \mathrm{~m}$ ) horizontal grid spacing and provides a maximum $5 \mathrm{~m}$ absolute vertical error (Becek, 2008; Garcin et al., 2009). In addition, high-resolution $(<1 \mathrm{~m})$ PLEIADES and $(5 \mathrm{~m})$ SPOT 5 images were used to focus on selected areas. This dataset was processed using GIS software (Global Mapper 15; www.globalmapper.com) to provide a high-resolution 3D image of geomorphological features. Topographic profiles, elevation differences, and slope values were obtained using Global Mapper 15 software.

The trajectory analysis method is a recent development based on the principles of sequence stratigraphy. This approach permits an estimate of the palaeoevolution of sea or lake levels based on the analysis of lateral and vertical migration of shore-dependent landforms (i.e. shelf, coastal wedge, or deltaic systems). Four categories of shoreline trajectories exist: ascending regressive, descending regressive, transgressive, and stationary. These reflect normal regression, forced regression, transgression, and stable trends, respectively. In terms of base-level evolution, normal regression and transgression indicate a rise in sea or lake levels, while forced regression reflects a water level decline. Here, we apply this method to decipher the evolution of Lake Turkana levels at the end of the AHP.

\section{Geomorphological analysis}

The Turkwel delta complex is $35 \mathrm{~km}$ long, forming one of the major deltaic systems of Lake Turkana (Fig. 1). It was developed as the shoreline migrated basinward, lowering from 450 to $360 \mathrm{~m}$ a.s.l. (Fig. 2). From west to east, five distinct progradational stages were identified (Fig. 2d). The first progradational stage forms a lobe protruding out from the average north-south palaeoshoreline, well defined by the $450 \mathrm{~m}$ a.s.l. elevation contour (red line in Fig. 2d). According to regional age models (Garcin et al., 2012; Forman et al., 2014; Bloszies et al., 2015), this first progradational stage 


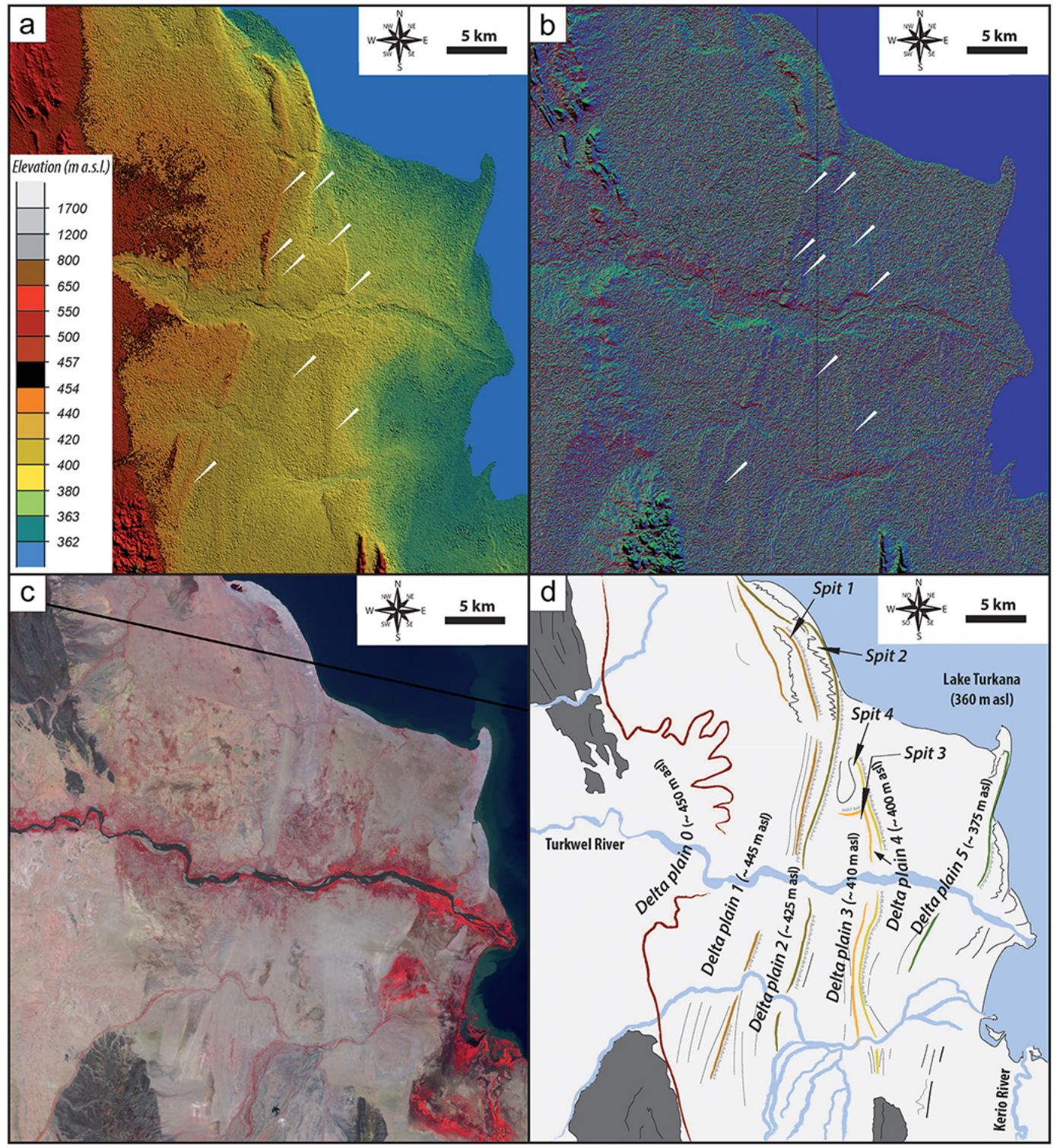

Figure 2. Turkwel delta complex. For location, see Fig. 1b. (a) Raw digital elevation model SRTM1 of the Turkwel delta. (b) Slope direction shading applied to the DEM SRTM1 of the Turkwel delta to highlight the steps separating the different plateaus. Markers display the correspondence between (a) the DEM SRTM1 and (b) the slope direction shading. (c) SPOT5 satellite image of the Turkwel delta. (d) Interpretative geomorphological map of the area showing five successive delta plains in addition to the oldest plain associated with the late AHP highstand.

marks the last Holocene highstand before the end of the AHP. Moving eastward, each of the three topographic profiles across the Turkwel delta complex (Fig. 3) show five slightly inclined plateaus separated by five abrupt 5 to $15 \mathrm{~m}$ high steps at ca. 445, 425, 410, 400, and $390 \mathrm{~m}$ a.s.l. (Fig. 4). Each plateau defines a different progradational stage. The plateaus are $3-5 \mathrm{~km}$ wide, and correspond to successively abandoned delta plains (Fig. 2d). To the north, these plateaus systematically end with palaeospits that document ancient, northward-flowing alongshore currents. The resulting landform reveals the Turkwel delta complex to be composed of successive asymmetric wave-dominated deltas (Bhattacharya and Giosan, 2003; Anthony, 2015) during most of its evolution, except in the early period associated with the AHP highstand. None of the plateaus exhibit evidence of significant erosion that would indicate reworking of the landforms subsequent to their deposition, except for the fluvial incision by the Turkwel River that progressively adjusted to base level fall. This supports the idea that the Turkwel delta complex represents a primary depositional landform displaying a continuous, comprehensive record of lake level evolution. Trajectory analysis, performed for the three tran- 


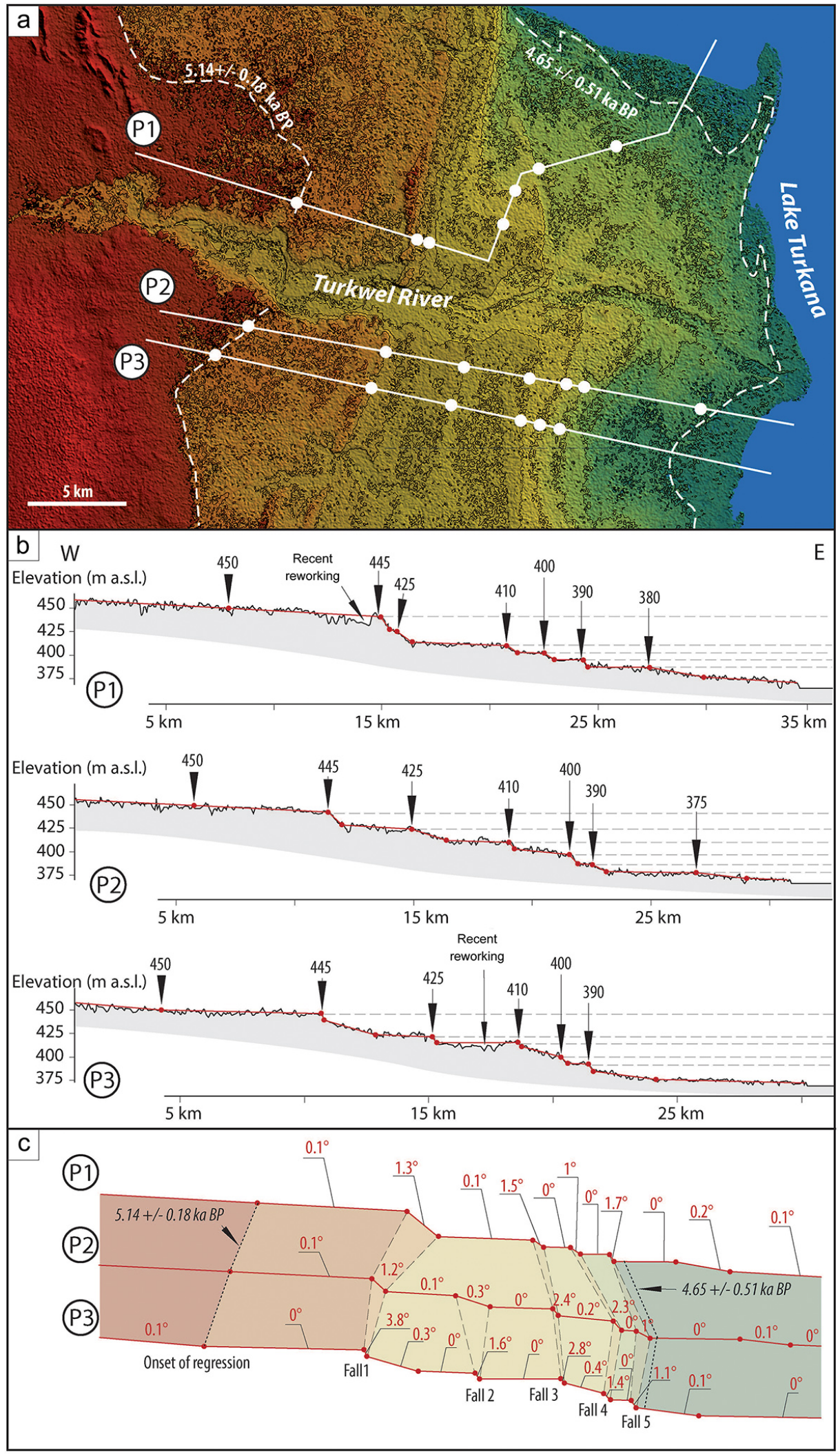

Figure 3. Geomorphological data for the Turkwel delta complex. For location, see Fig. 1b. (a) SRTM1 images were processed to display a digital elevation model of the Turkwel delta complex. Locations of the topographic transects are presented. (b) Topographic transects P1, P2, and P3. (c) Trajectory analyses show that the overall forced regressive trend $\left(<0.4^{\circ}\right)$ is punctuated by five steeper slopes $\left(1\right.$ to $\left.3.8^{\circ}\right)$ revealing short-term increases in the rates of lake level fall. 

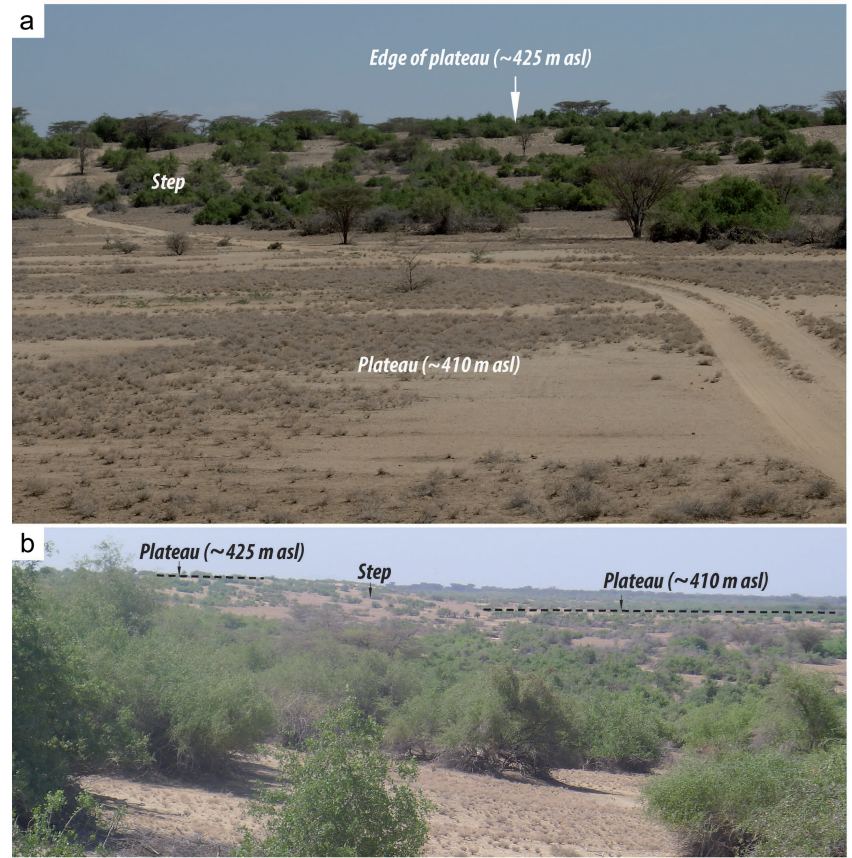

Figure 4. Landforms from the Turkwel delta. (a) Front view of a step grading downward to a plateau. (b) Side view of the same step separating two plateaus.

sects across the Turkwel delta complex along its progradation axes (Fig. 3), reveals that the plateaus are continuous, having slightly descending regressive trajectories $\left(<0.4^{\circ}\right)$. The five abrupt steps that separate plateaus have much higher slope gradients $\left(1\right.$ to $\left.3.8^{\circ}\right)$, and are also defined as descending regressive trajectories. The trajectories reflect a progradation associated with a general lake level fall that meets the definition of a forced regression (Posamentier et al., 1992). The five abrupt steps reflect recurrent, short-lived increases in the rate of lake level fall that evidence a stepwise forced regression at the end of the AHP.

In the eastern Omo River valley (Fig. 1), topographic profiles along two fossil spits (Fig. 5) confirm this interpretation. Both spits show successive steps starting at elevations similar to those observed in the Turkwel delta complex (ca. 445, 425, 410, and $400 \mathrm{~m}$ a.s.l.; Fig. 3). These additional observations strongly support features in the Turkwel delta complex that reflect a stepwise forced regression of Lake Turkana at the end of the AHP.

\section{Chronological framework}

Humid conditions related to the AHP broadly prevailed over Africa from 14.8 to $5.5 \mathrm{ka}$ cal BP (deMenocal et al., 2000; Shanahan et al., 2015). Several lake level curves developed from Lake Turkana provide records of the regional moisture history over the Holocene (Garcin et al., 2012; Forman et al., 2014; Bloszies et al., 2015). Based on surveys of raised
Holocene beach ridges coupled with dated archaeological sites, these studies also provide a relatively robust chronological framework for its regression at the end of the AHP. Garcin et al. (2012) initially estimated the onset of the last lake level fall in Lake Turkana at ca. $5.27 \pm 0.36 \mathrm{kacal}$ BP based on radiocarbon ages obtained from shells preserved in palaeoshorelines. Subsequently, using a similar methodology, Forman et al. (2014) proposed that the age of this last regression occurred between 5.5/5.0 and $4.6 \mathrm{kacal} \mathrm{BP}$ associated to a lake level fall from 440 to $380 \mathrm{~m}$ a.s.l. Finally, Bloszies et al. (2015) proposed an onset of the last regression of the AHP starting at $5.18 \pm 0.12 \mathrm{kacal} \mathrm{BP}$ (shells at $90 \mathrm{~m}$ above the modern Lake Turkana; sample SNU12589 ) and finishing at $4.58 \pm 0.25 \mathrm{ka} \mathrm{BP}$ (optically stimulated luminescence (OSL) age reused from Forman et al., 2014; sample UIC2319) associated with a lake level fall from 450 to $375 \mathrm{~m}$ a.s.l. Based on these published data, we carried out minor complementary processing in order to refine the chronology. First, we recalibrated sample SNU12-589, considered to provide the age of the onset of the last regression. Using INTCAL13 (Reimer et al., 2013), the onset of the last regression is now $5.14 \pm 0.18 \mathrm{kacal} \mathrm{BP}(4.51 \pm 0.06 \mathrm{ka}$ ${ }^{14} \mathrm{CBP}$ ). Second, we converted the OSL age, representing the end of the last regression of $4.58 \pm 0.5 \mathrm{ka} \mathrm{BP}(2 \sigma)$ by Forman et al. (2014), to radiocarbon years. Forman et al. (2014) provide six samples that were dated by both OSL and radiocarbon methods. Despite the limited number of samples, we ran a linear regression to propose a statistical relationship between OSL and radiocarbon ages. Based on this correlation $\left(\operatorname{age}_{(\mathrm{OSL})}=0.98386063 \times \operatorname{age}_{\left(\begin{array}{c}\text { C(calibrated) } \\ { }^{14}\end{array}\right.} ;\right.$ $b$ (the intercept) has been forced to $0 ; r^{2}=0.9942$ ), the age of the end of the last regression is now estimated at $4.65 \pm 0.51 \mathrm{kacal} \mathrm{BP}\left(4.14 \pm 0.17 \mathrm{ka}{ }^{14} \mathrm{CBP}\right)$. As the investigated portion of the Turkwel delta complex is located between 450 and $375 \mathrm{~m}$ a.s.l., the landforms are considered to have developed between $5.14 \pm 0.18$ and $4.65 \pm 0.51 \mathrm{ka} \mathrm{cal} \mathrm{BP}$.

Based on this time interval, the last regression of Lake Turkana would, at the longest, span a period from 5.32 to $4.14 \mathrm{kacal} \mathrm{BP}$. Converting this longest potential time interval as radiocarbon ages (i.e. the interval between 4.57 and $3.97 \mathrm{ka}{ }^{14} \mathrm{C} \mathrm{BP}$ ), a mean age of $4.27 \pm 0.3 \mathrm{ka}{ }^{14} \mathrm{C} \mathrm{BP}$ is established to thereby allow calibration and provide a probability curve. The probability curve reveals a ca. $43 / 44 \%$ probability that the last regression occurred precisely between 5.14 and $4.65 \mathrm{ka}$ cal BP.

\section{Discussion}

\subsection{Origin of Lake Turkana lake level evolution}

Lake level fluctuations may result from changes in the quantity of water supply to a lake, from altered evapotranspiration rates within the catchment area, or from modifications 


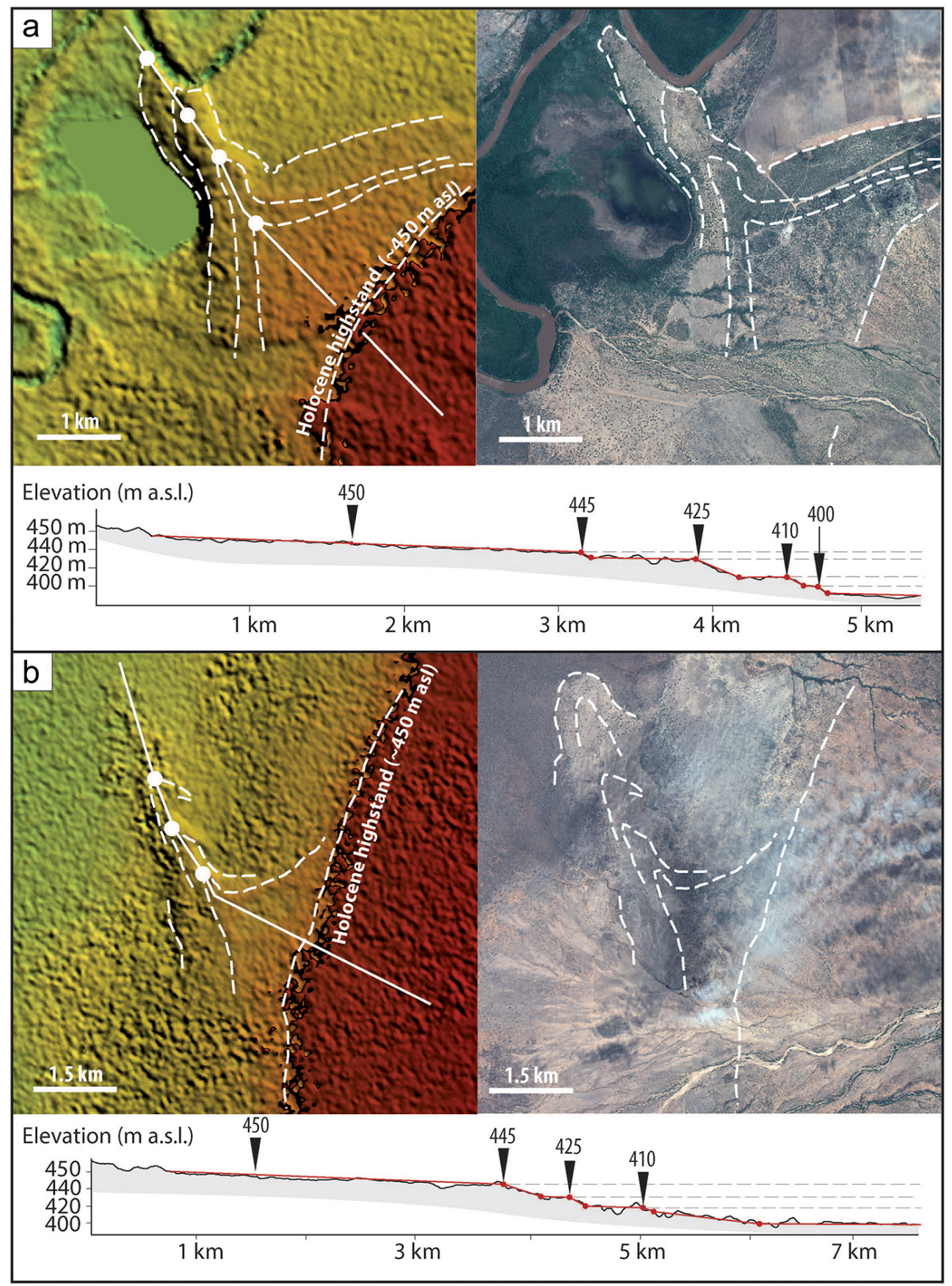

Figure 5. Fossil spits along the eastern Omo River valley (for location see Figure1b) from SRTM 1 (left panel) and from PLEIADES images (right panel). The fossil spits are outlined by dashed white lines. They display plateaus interrupted at similar elevations to those of the Turkwel delta.

in basin physiography. These changes may originate from a number of potential external forcing processes, among which the most commonly considered are tectonism and climate. Given the short timescale considered in this study, abrupt falls in lake level cannot be attributed to tectonism and any associated physiographic modification of the Lake Turkana basin. Vertical crustal movements occur over much longer time periods and the rate of subsidence in the basin is too low (i.e. $0.4 \mathrm{~m} \mathrm{ka}^{-1}$ at the Eliye Spring well site; Morley et al., 1999) to explain several lake level falls of $>5 \mathrm{~m}$ each occurring within 1000 years. Moreover, vertical displacements at this scale would require earthquakes having a magnitude $>9$ (Pavlides and Caputo, 2004). Earthquakes of this magnitude are unknown in the area and are not compatible with rift 


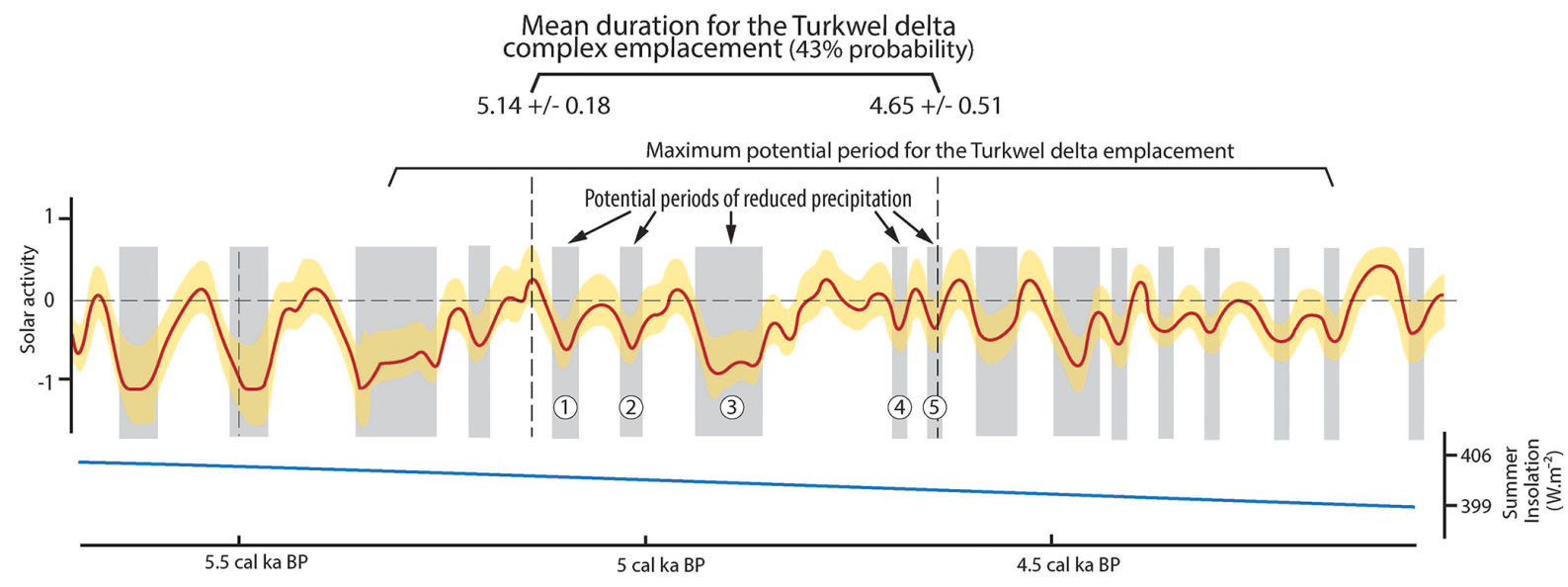

Figure 6. The red curve presents total solar irradiance (40-year moving average) relative to the value of the PMOD composite during the solar cycle minimum of the year 1986 (1365.57 $\mathrm{W} \mathrm{m}^{-2}$; Steinhilber et al., 2009) for the period contemporaneous with AHP regression of Lake Turkana. The shaded band (yellow) represents $1 \sigma$ uncertainty. The blue curve represents the precessional curve covering the same time period (http://www.imcce.fr/Equipes/ASD/insola/earth/online/). Grey stripes highlight solar activity minima.

systems. Finally, volcanic activity is known to have occurred during the Late Quaternary (Karson and Curtis, 1994), but its timing is not well constrained. Repeated pulses of accelerated subsidence related to successive emptying of a magma chamber are also inconsistent with the limited amount of magma observed in the basin. Indeed, there is no regional magmatic effusion observed that would have caused sudden subsidence. Rather, magmatism corresponded to episodic, spatially limited effusions that formed the north, central, and south islands. As such, it is difficult to attribute the abrupt nature of the accelerated lake level falls to tectonism and magmatism, thus rendering climate variability as the most likely forcing mechanism.

During the Holocene, the overall climate pattern in East Africa was governed by insolation patterns related to changes in precessional orbital parameters of the Earth (Barker et al., 2004). Links between insolation and hydrology are now well established for this region, with monsoonal rainfall intensity being strongly correlated with summer insolation. In the early Holocene, an increase in summer insolation produced wetter conditions over much of the African continent leading to the establishment of the AHP and an expansion of lakes (deMenocal et al., 2000; Shanahan et al., 2015). Subsequently, the overall contraction of lakes at the end of the AHP is generally attributed to decreased precipitation related to an orbitally controlled reduction in summer insolation (deMenocal et al., 2000; deMenocal and Tierney, 2012; Bard, 2013; Shanahan et al., 2015) Insolation changes drive modifications in rainfall amounts through the strengthening or weakening of local climate processes. In the Lake Turkana area, Junginger et al. (2014) suggest that the increase in precipitation during the AHP is mainly a result of a north-eastward shift of the Congo Air Boundary (CAB). The $\mathrm{CAB}$ is a north-east-south-west-oriented convergence zone presently located west of the Lake Turkana area. This convergence zone shifts eastward in response to an enhanced atmospheric pressure gradient between India and East Africa during Northern Hemisphere insolation maxima (Junginger and Trauth, 2013; Junginger et al., 2014). When the CAB moves eastward over the Turkana area, precipitation is expected to increase significantly. As the five abrupt accelerations in lake level fall require short-term accentuated decreases in precipitation, we propose that these five periods of significantly reduced rainfall amounts are related to short-term decreases in insolation that repeatedly displaced the CAB. In our opinion, at such decadal to centennial timescales, variations in solar activity appear as the most likely parameter to explain variations in insolation.

\subsection{Linking solar activity and palaeohydrology}

Establishing links between short-term (decadal-scale) solar activity and climate change remains a point of debate. Periodicities in solar activity, such as the 11-year sunspot cycle, the Gleissberg cycle (80-90 years; Peristykh and Damon, $2003)$ or the de Vries cycle ( 200 years; Raspopov et al., 2008) have been identified in Holocene palaeoenvironmental records and indicate a possible forcing by short-term solar activity on climate (Crowley, 2000; Bond et al., 2001; Gray et al., 2013). In the Lake Turkana area, Halfman et al. (1994) unravelled the expression of the 11-year sunspot cycle during the last $4 \mathrm{ka}$ through a time-series analysis of sediment cores. Several authors link more arid periods inferred from lacustrine records with solar activity minima (Verschuren et al., 2000; Stager et al., 2002; Junginger et al., 2014). The ability of lakes to record changes in palaeohydrology attributed to variations in solar activity may be enhanced for "amplifier lakes" (Street, 1980). Indeed, relatively modest changes in climate are amplified into significant lake level fluctuations 
due to their specific morphology. As an amplifier lake, Lake Turkana should be sensitive to variations in precipitation induced by small variations in insolation.

When we compare the proposed chronological framework with the solar activity curve from Steinhilber et al. (2009), we observe between one and fourteen solar activity minima during the minimum and maximum potential periods of regression, respectively (Fig. 6). During the time period consistent with the average duration of the regression -490 years between 5.14 and $4.65 \mathrm{kacal}$ BP - five solar activity minima are observed. Given that the number of these minima matches the number of abrupt lake level falls, this may suggest a causal link between the short-term variability of solar activity and the lake level changes in Lake Turkana at the end of the AHP. Even though robust chronological correlations are not yet available between these short-term accelerations of lake level fall and solar activity minima, we propose a mechanism linking solar activity and lake level evolution. We suggest that periods of solar activity maxima would be able to compensate for the precession-induced reduction of insolation. The relatively limited reduction of insolation would have led to a relatively stable position for the $\mathrm{CAB}$ over the Lake Turkana area. As such, this would favour a reduced rate of lake level fall due to slowly decreasing rates of precipitation amounts. However, when short-term solar activity minima are coupled with the precession-related insolation decrease, the $\mathrm{CAB}$ would have migrated rapidly westward, resulting in a drastic reduction of rainfall and, as a consequence, producing a rapid fall in lake level. As such, alternations of solar activity maxima and minima could explain the geomorphological evidence for a long-term forced regression interspersed by short-term accelerations in the rate of lake level fall at the end of the AHP.

\section{Conclusions}

Geomorphic analysis (i.e. trajectory analysis) of the Turkwel delta complex reveals, for the first time, a stepwise lake level fall of Lake Turkana during its last forced regression at the end of the African Humid Period. Five rapid falls in lake level were identified, intercalated with periods of slower lake level fall. These five rapid falls in lake level reflect five short-term periods associated with drastic decreases in precipitation. We propose that these abrupt, short-term decreases in precipitation are associated with insolation minima altering the position of the Congo Air Boundary, the large-scale circulation system responsible for regional precipitation patterns over this region. Furthermore, we propose that the short-term changes in insolation are caused by variations in solar activity. The next research step would be to precisely date each plateau and each step to a specific solar maximum and minimum, respectively. Nevertheless, existing dating methods do not, however, provide precise enough ages at such decadal to centennial timescales.

\section{Data availability}

SRTM digital elevation model is free to access using the website: earthexplorer.usgs.gov. PLEIADES and SPOT images were bought thanks to the support of the CNES and are not freely available.

Acknowledgements. This work is a contribution of the Rift Lake Sedimentology project (RiLakS) funded by Total Oil Company. Satellite images (SPOT and PLEIADES) were acquired thanks to the support of the CNES/ISIS program. Finally, we are grateful to Murray Hay (Maxafeau Editing Services) for verifying the English within the text.

Edited by: A. Stroeven

Reviewed by: two anonymous referees

\section{References}

Anthony, E. J.: Wave influence in the construction, shaping and destruction of river deltas: A review, Mar. Geol. 361, 53-78, 2015.

Bard, E.: Out of the African Humid Period, Science, 342, 808-809, 2013.

Barker, P. A., Talbot, M. R., Street-Perrott, F. A., Marret, F., Scourse, J., and Odada, E. O.: Late Quaternary climatic variability in intertropical Africa, in: Past climate variability through Europe and Africa, edited by: Battarbee, R. W., Gasse, F., and Strickley, C. E., Springer, Dordrecht, 2004.

Becek, K.: Investigating error structure of shuttle radar topography mission elevation data product, Geophys. Res. Lett. 35, L15403, doi:10.1029/2008GL034592, 2008.

Bhattacharya, J. P. and Giosan, L.: Wave-influenced deltas: geomorphological implications for facies reconstruction, Sedimentology, 50, 187-210, 2003.

Bloszies, C., Forman, S. L., and Wright, D. K.: Water level history for Lake Turkana, Kenya in the past 15000 years and a variable transition from the African Humid Period to Holocene aridity, Global Planet. Change, 132, 64-76, 2015.

Bond, G., Kromer, B., Beer, J., Muscheler, R., Evans, M. N., Showers, W., Hoffman, S., Lotti-Bond, R., Hajdas, I., and Bonani, G.: A pervasive millennial-scale cycle in North Atlantic Holocene and glacial climates, Science, 278, 1257-1266, 2001.

Butzer, K. W.: The Holocene lake plain of Lake Rudolph, Phys. Geogr., 1, 42-58, 1980.

Crowley, T.: Causes of climate change over the past 1000 years, Science, 289, 270-277, 2000.

deMenocal, P. B. and Tierney, J. E.: Green Sahara: African Humid Periods paced by Earth's orbital changes, Nature Educ. Knowl., 3, 12, 2012.

deMenocal, P. B., Ortiz, J., Guilderson, T., Adkins, J., Sarnthein, M., Baker, L., and Yarusinsky, M.: Abrupt onset and termination of the African Humid Period: rapid climate responses to gradual insolation forcing, Quaternary Sci. Rev., 19, 347-361, 2000.

Forman, S. L., Wright, D. K., and Bloszies, C.: Variations in water level for Lake Turkana in the past 8500 years near Mt. Porr, Kenya and the transition from the African Humid Period to Holocene aridity, Quaternary Sci. Rev., 97, 84-1014, 2014. 
Garcin, Y., Junginger, A., Melnick, D., Olago, D. O., Strecker, M. R., and Trauth, M. H.: Late Pleistocene rise and collapse of Lake Suguta, northern Kenya Rift, Quaternary Sci. Rev., 28, 911-925, 2009.

Garcin, Y., Melnick, D., Strecker, M. R., Olago, D., and Tiercelin, J.-J.: East African mid-Holocene wet-dry transition recorded in palaeo-shorelines of Lake Turkana, northern Kenya Rift, Earth Planet. Sc. Lett., 331-332, 322-334, 2012.

Gray, L., Scaife, A. A., Mitchell, D. M., Osprey, S., Ineson, S., Hardiman, S., Butchart, N., Knight, R., Sutton, R., and Kodera, $\mathrm{K}$.: A lagged response to the 11-year solar cycle in observed winter Atlantic/European weather patterns, J. Geophys. Res., 118, 13405-13420, 2013.

Halfman, J. D., Johnson, T. C., and Finney, B. P.: AMS dates, stratigraphic correlations and decadal climatic cycles for the past $4 \mathrm{ka}$ at Lake Turkana, Kenya, Palaeogeogr. Palaeocl., 111, 83-98, 1994.

Helland-Hansen, W. and Hampson, G.: Trajectory analysis: concepts and application, Basin Res., 21, 454-483, 2009.

Junginger, A. and Trauth, M. H.: Hydrological constraints of paleoLake Suguta in the Northern Kenya Rift during the African Humid Period (12-5 ka BP), Global Planet. Change, 111, 174-188, 2013.

Junginger, A., Roller, S., Olaka, L. A., and Trauth, M. H.: The effects of solar irradiation changes on the migration of the Congo Air Boundary and water levels of paleo-Lake Suguta, Northern Kenya Rift, during the African Humid Period (15-5 ka BP), Palaeogeogr. Palaeocl., 396, 1-16, 2014.

Karson, J. A. and Curtis, P. C.: Quaternary volcanic centres of the Turkana Rift, Kenya, J. Afr. Earth Sci., 18, 15-35, 1994.

Kröpelin, S., Verschuren, D., Lézine, A.-M., Eggermont, H., Cocquyt, C., Francus, P., Cazet, J.-P., Fagot, M., Rumes, B., Russell, J. M., Darius, F., Conley, D. J., Schuster, M., von Suchodoletz, H., and Engstrom, D. R.: Climate-driven ecosystem succession in the Sahara: The past 6000 years, Science, 320, 765-768, 2008.

Kutzbach, J. E. and Street-Perrott, F. A.: Milankovitch forcing of fluctuations in the level of tropical lakes from 18 to $0 \mathrm{kyr}$ BP, Nature, 317, 130-134, 1985.

Kuper, R. and Kröpelin, S.: Climate-controlled Holocene occupation in the Sahara: Motor of Africa's evolution, Science, 313, 803-807, 2006.

Liu, Z., Wang, Y., Gallimore, R., Gasse, F., Johnson, T., deMenocal, P., Adkins, J., Notaro, M., Prentice, I. C., Kutzbach, J., Jacob, R., Behling, P., Wang, L., and Ong, E.: Simulating the transient evolution and abrupt change of Northern Africa atmosphere-oceanterrestrial ecosystem in the Holocene, Quaternary Sci. Rev., 26, 1818-1837, 2007.

Morley, C. K., Karanja, F. M., Wescott, W. A., Stone, D. M., Harper, R. M., Wigger, S. T., and Day, R. A.: Geology and geophysics of the western Turkana basins, Kenya, Am. Assoc. Petrol. Geol., 44, 19-54, 1999.

Morrissey, A. and Scholz, C. A.: Paleohydrology of Lake Turkana and its influence on the Nile River system, Palaeogeogr. Palaeocl., 403, 88-100, 2014.

Nutz, A., Schuster, M., Ghienne, J.-F., Roquin, C., and Bouchette, F.: Wind-driven waterbodies: A new category of lake within an alternative sedimentologically-based lake classification, J. Paleolimnol., doi:10.1007/s10933-016-9894-2, 2016.
Owen, R. B., Barthelme, J. W., Renaut, R. W., and Vincens, A.: Paleolimnology and archaeology of Holocene deposits north-east of Lake Turkana, Kenya, Nature, 298, 523-529, 1982.

Patricola, C. M. and Hook, K. H.: Sub-Saharan Northern African climate at the end of the twenty-first century: Forcing factors and climate change processes, Clim. Dynam., 37, 1165-1188, 2011.

Pavlides, S. and Caputo, R.: Magnitude versus faults' surface parameters: quantitative relationships from the Aegean Region, Tectonophysics, 380, 159-188, 2004.

Peristykh, A. N. and Damon P. E.: Persistence of the Gleissberg 88-year solar cycle over the last 12000 years: Evidence from cosmogenic isotopes, J. Geophys. Res., 108, 1003, doi:10.1029/2002JA009390, 2003.

Posamentier, H. W., Allen, G. P., James, D. P., and Tesson, M.: Forced regressions in a sequence stratigraphic framework: concepts, examples, and exploration significance, Am. Assoc. Petrol. Geol. Bull., 76, 1687-1709, 1992.

Rabus, B., Eineder, M., Roth, A., and Bamler, A.: The shuttle radar topography mission - a new class of digital elevation models acquired by spaceborne radar, ISPRS J. Photogram. Remote Sens., 57, 241-262, 2003.

Raspopov O. M., Dergachev, V. A., Esper, J., Kozyreva, O. V., Frank, D., Ogurtsov, M., Kolström, T., and Shao, X.: The influence of the de Vries (200-years) solar cycle on climate variations: Results from the Central Asian Mountains and their global link, Palaeogeogr. Palaeocl., 259, 6-16, 2008.

Reimer, P. J., Bard, E., Bayliss, A., Beck, J. W., Blackwell, P. G., Bronk Ramsey, C., Buck, C. E., Cheng, H., Edwards, R. L., Friedrich, M., Grootes, P. M., Guilderson, T. P., Haflidason, H., Hajdas, I., Hatté, C., Heaton, T. J., Hoffmann, D. L., Hogg, A. G., Hughen, K. A., Kaiser, K. F., Kromer, B., Manning, S. W., Niu, M., Reimer, R. W., Richards, D. A., Scott, E. M., Southon, J. R., Staff, R. A., and Turney, C. S. M., INTCAL13 and MARINE13 radiocarbon age calibration curves, 0-50 000 years Cal BP, Radiocarbon, 55, 1869-1887, 2013.

Renssen, H., Brovkin, V., Fichefet, T., and Goosse, H.: Simulation of the Holocene climate evolution in Northern Africa: The termination of the African Humid Period, Quatern. Int., 150, 95-102, 2006.

Shanahan, T. M., McKay, N. P., Hughen, K. A., Overpeck, J. T., Otto-Bliesner, B., Heil, C. W., King, J., Scholz, C. A., and Peck, J.: The time-transgressive termination of the African Humid Period, Nat. Geosci., 8, 140-144, 2015.

Stager, J. C., Mayewski, P. A., and Meeker, L. D.: Cooling cycles, Heinrich event 1, and the desiccation of Lake Victoria, Palaeogeogr. Palaeocl., 183, 169-178, 2002.

Steinhilber, F., Beer, J., and Fröhlich, C.: Total solar irradiance during the Holocene, Geophys. Res. Lett., 36, L19704, doi:10.1029/2009GL040142, 2009.

Street, F. A.: The relative importance of climate and local hydrogeological factors in influencing lake-level fluctuations, Palaeoecology of Africa, 12, 83-118, 1980.

Street, F. A. and Grove, A. T.: Environmental and climatic implications of late Quaternary lake level fluctuations in Africa, Nature, 261, 385-390, 1976.

Street-Perrott, F. A. and Roberts, N.: Fluctuations in closed basin lakes as indicators of past atmospheric circulation patterns, in: Variations in the global water budget, edited by: Street-Perrott, 
F. A., Beran, M., and Ratcliffe, R.A . S., Dordrecht, Reidel, 331345, 1983.

Tierney, J. E. and deMenocal, P.: Abrupt shifts in Horn of Africa hydroclimate since the Last Glacial Maximum, Science, 342, 843846, 2013.

Tierney, J. E., Lewis, S. C., Cook, B. I., LeGrande, A. N., and Schmidt, G. A.: Model, proxy and isotopic perspectives on the East African Humid Period, Earth Planet. Sc. Lett., 307, 103$112,2011$.
Verschuren, D., Laird, K. R., and Cumming, B. F.: Rainfall and drought in equatorial east Africa during the past 1100 years, Nature, 403, 410-414, 2000. 